\title{
DEMAND FOR SWEETPOTATO QUALITY USING THE HEDONIC PRICE MODEL IN NORTHWESTERN LEYTE $\mathbb{1}$
}

\author{
Merlita D. Veloso \\ College of Education and Agricultural Technology \\ Leyte State University, Villaba, Leyte
}

and

Jose M. Alkuino, Jr.

Department of Economics, College of Engineering and Agri-Industries, Leyte State University

Visca, Baybay, Leyte

\section{ABSTRACT}

Research conducted to estimate implicit prices of sweetpotato using the Hedonic Price Model revealed that consumers attach economic importance to sweetpotato quality. Both urban and rural consumers were responsive to changes in quality characteristics. The price paid by rural consumers is affected significantly by age of consumers and quality characteristics such as color, shape and starch content. The price paid by urban consumers is strongly influenced by color, shape, protein, starch, sugar and fiber content of sweetpotatoes. Among income classes, low income consumers were more discriminating than high-income consumers.

SEY WORDS: Implicit price. Pricing. Hedonic Price Model. Sweetpotato quality.

11 Part of the M.S. thesis of the senior author 


\section{INTRODUCTION}

Demand for agricultural products like sweetpotato offers information on how consumption patterns change as consumer characteristics change. According to the traditional economic theory, given the taste and preferences, prices and consumer's income are the main determinants of consumer demand (Coleman and Young, 1989). Several economists argue that there are other determinants of demand related to product characteristics and properties such as odor, color, shape, texture and nutrient content (Houthakker, 1952; Lancaster, 1966; Rosen, 1974; Becker, 1965; Ladd and Suvannunt, 1976; Golan and Shalit, 1993; Puttock et al., 1990; and Abansi, 1991). In sweetpotato, economic theory suggests that given the consumer's taste and preferences, the demand will be determined by price of the product, prices of other products, consumer's income and a host of other socio-economic variables. However, this traditional approach provides no guide on demand of specified change in the characteristics of the product. An alternative approach in determining the factors affecting consumer's demand for sweetpotato is presented in this study.

\section{METHODOLOGY}

Variations in consumer preferences were gathered by selecting the market in Ormoc City representing urban area and the market in Villaba representing the rural area. 


\section{Sampling Procedure}

A sampling frame comprising regular consumers and with reference to their per capita income was developed to identify 'the respondents. After two weeks of directly observing and interviewing retailers, the total number of regular consumers who bought sweetpotato in each selected market was determined. There were 570 regular consumers in the urban market and 450 consumers in the rural market. The consumers were divided into two groups based on the per capita income per month food threshold level for Region 8 . Respondents earning less than $\$ 325.00$ per month comprised the low income group and those earning more were regarded as high income earners. Stratified random sampling was used in the selection of respondents. A random sampling representing $10 \%$ of the population was drawn from each stratum generating a total of 102 respondents. Of these, 57 were urban respondents and 45 were rural respondents. There were 28 low income earners and 74 high income earners.

\section{Data Collection}

The respondents were personally interviewed to obtain their preferences for sweetpotato quality. The quality characateristics included size of roots, color, texture, shape, taste or flavor.

Interviews were conducted while consumers were purchasing sweetpotato in the market to ensure simultaneous collection of samples for laboratory analysis at PhilRootcrops, Visca, Baybay, Leyte. 
Chemical analysis included dry matter content, protein content, starch content, sugar content and crude fiber content.

\section{Data Analysis}

Data analysis was based on the theory of consumer demand for characteristics as developed by Ladd and Suvaninunt (1976). For the characteristics that defined quality in sweetpotato, the implicit characteristics were determined by least squares regression of observed market price on measures of quality in the form:

$$
\begin{aligned}
& \text { N } \\
& P s=\Sigma X s j P s j+u \\
& J=1 \\
& \text { Where: } \text { Ps } \quad=\text { market price of sweetpotato }(\mathrm{R} / \mathrm{kg}) \\
& X s j=\text { quantity of characteristic } j \text { in one unit of } \\
& \text { sweetpotato } \\
& \text { Psj = implicit value of characteristic } \mathrm{j} \\
& \mathrm{u}=\text { error term }
\end{aligned}
$$

The independent variables (Xsj's) explained the variance in the price of sweetpotato while the estimated coefficient (Psj) measured the implicit values of each characteristic.

For the characteristics that defined quality in sweetpotato which were normally-scaled, analysis of variance was employed to determine if price was significantly affected by such determinants as color, shape, texture and taste/flavor. 
Measures of quality characteristics were as follows:

Physical Characteristics (Nominally Scaled):

Size of roots

Color (skin)

Shape

Texture

Taste/flavor

Dry matter content

Protein content

Starch content

Sugar content

Crude fiber length in centimeters

1 - white

2 - yellow.

3 - light yellow

4 - orange

5 - purple

1 - cylindrical or ovate

2 - elongated

3 - round

4 - irregular

$1-$ dry

2-wet

1 - sweet

2 - sweet, dry

3 - non-sweet, dry

4 - non-sweet, wet

Chemical Characteristics

Percent of fresh weight

Percent of dry weight

Percent of dry weight

Percent of dry weight

Grams dry fiber / Grams fresh tissue 
Equation 1 of the form presented above provided the familiar linear functional equation used to estimate hedonic prices, Psj, from observation of characteristics Xsj and market prices, Ps, of different qualities of sweetpotato.

A vector of consumer traits that pinpoint the nature of preferences among different groups of consumers were also incorporated in the model. This can be in the form:

$$
\begin{aligned}
& P S=f(X s j, a) \\
& \text { Where: } \text { Ps = market price of sweetpotato } \\
& X s j=\text { quantity of sweetpotato characteristics } \\
& \text { a }=\text { vector of consumer traits which include: } \\
& \begin{aligned}
\text { age } & =\text { years old } \\
\text { education }= & \text { number of years in school } \\
\text { occupation }= & \text { number with white collar jobs, blue } \\
& \text { collar jobs and unemployed } \\
\text { income }= & \text { pesos per capita income per month } \\
& \text { (low income group = less than } \\
& \text { R325.00 per month; high income } \\
& \text { group }=\text { greater than } ₹ 325 \text { per } \\
& \text { month) }
\end{aligned}
\end{aligned}
$$

Ordinary Least Squares (OLS) was used to estimate the relationships for each location and income groups. The Chow test (Fisher, 1970) was applied to determine if the estimated price and 
quality relationships differed significantly between rural and urban consumers and find out the equality of coefficients of urban and rural regressions.

\section{RESULTS AND DISCUSSION}

Agricultural researchers need to have a way of measuring how important are quality characteristics to consumers in order to incorporate them into new varieties. Estimates of hedonic prices for characteristics that define quality in sweetpotato at the consumers level in Northwestern Leyte demonstrate how price of sweetpotato can be affected by quality characteristics such as colori, shape, texture and taste/flavor through the analysis of variance.

Rural consumers (64\%) dominated the low income group while urban households constituted the majority $(64 \%)$ of the high income group. Age did not vary significantly between the two consumer groups. However, the average number of years in school significantly increased as the income level went up. Moreover, rural and urban consumers differred significantly in age, education and income level.

With regard to sweetpotato samples, there was a significant difference in skin color, texture and taste/flavor among the samples from the two markets. Chemical analysis showed that percent dry matter, starch, sugar and crude fiber content of the urban samples were all significantly different from those of the rural samples. Average price was considerably higher $($ $1.47 / \mathrm{kg})$ in urban than in rural markets. 
Between the two income groups, only size of root and skin reflected significant difference. No significant difference in shape, texture and tastefflavor in both income levels was obtained. Crude fiber content and protein content decreased whereas starch and sugar content increased as income increased. There was little variation in dry matter content of sweetpotato bought by high income consumers.

\section{Hedonic Relationships and Implicit Prices}

Characteristics affecting sweetpotato prices in urban and rural areas are presented in Table 1 and the calculated implicit prices for these characteristics are in Table 2. For the urban consumers, protein, starch, sugar and crude fiber content were very important determinants of price. However, contrary to expectation, these determinants showed an inverse relationship with price except for crude fiber which reflected a positive relationship. Consumer traits such as age, education and income were insignificant determinants of urban sweetpotato prices. For the rural consumers, characteristics that showed no significant relationship with price were size of roots, protein content, crude fiber, dry matter and sugar content. The only significant but negative determinant of price was starch content. Among the consumers traits, age was found to have a positive and significant effect. Older homemakers purchased high priced varieties. 
Table 1. Estimated implicit price function by location, Ormoc and Villaba, Northwestern Leyte.

\begin{tabular}{|c|r|r|r|}
\hline \multirow{2}{*}{ Item } & \multicolumn{3}{|c|}{ Location } \\
\cline { 2 - 4 } & \multicolumn{1}{|c|}{ Urban } & \multicolumn{1}{c|}{ Rural } & \multicolumn{1}{c|}{ Both } \\
\hline Sweetpotato Characteristics & & & 0.09 \\
\hline Size of root & 0.10 & 0.02 & $(1.28)$ \\
\hline & $(0.93)$ & $(0.107)$ & 0.36 \\
\hline Dry matter content & 0.07 & 1.23 & $(-1.43)$ \\
\hline Protein content & $(0.21)$ & $(-1.67)$ & $0.19^{*}$ \\
\hline & $0.28^{\star *}$ & 0.01 & $(-2.72)$ \\
\hline Starch content & $(-3.46)$ & $(0.071)$ & $0.76^{\star}$ \\
\hline & $1.20^{\star *}$ & $1.21^{*}$ & $(-5.03)$ \\
\hline Sugar content & $(-6.82)$ & $(-2.10)$ & $0.41^{*}$ \\
\hline & $0.56^{\star *}$ & 0.29 & $(-6.00)$ \\
\hline Crude fiber content & $(-7.75)$ & $(-1.35)$ & $0.44^{\star *}$ \\
\hline & $0.68^{\star *}$ & 0.28 & $(8.89)$ \\
\hline & $(10.73)$ & $(1.64)$ & \\
\hline Consumer trait & & & 0.001 \\
\hline Age & & & $(-0.03)$ \\
\hline & 0.014 & $0.30^{*}$ & 0.01 \\
\hline Education & $(0.40)$ & $(4.91)$ & $(0.78)$ \\
\hline & 0.02 & 0.09 & 0.0003 \\
\hline Income & $(1.33)$ & $(0.52)$ & $(0.02)$ \\
\hline & 0.007 & 0.0004 & $0.07^{*}$ \\
\hline Location & $(0.40)$ & $(-0.12)$ & $(6.37)$ \\
\hline Summary Statistics & & & 0.69 \\
\hline R2 & & & $29.29^{\star \star}$ \\
\hline F & & & 0.04 \\
\hline SEE & 0.84 & 0.50 & 102 \\
\hline N & $29.30^{\star *}$ & 4.88 & \\
\hline \hline
\end{tabular}

1 Figure in parenthesis are $\mathrm{t}$-values

${ }^{*}=$ significant at $5 \%$ level; ${ }^{* *}=$ significant at $1 \%$ level; 
Table 2. Mean implicit prices (R/unit) of characteristics paid by urban consumers, Ormoc, Northwestern, Leyte.

\begin{tabular}{|l|r|r|r|}
\hline \multirow{2}{*}{\multicolumn{1}{c|}{ Characteristics }} & \multicolumn{3}{|c|}{ Location } \\
\cline { 2 - 4 } & \multicolumn{1}{|c|}{ Urban } & \multicolumn{1}{c|}{ Rural } & \multicolumn{1}{c|}{ Both } \\
\hline Size of roots & 0.08 & 0.01 & 0.07 \\
\hline Dry matter content & 0.04 & -0.79 & -0.23 \\
\hline Protein content & -0.68 & 0.02 & -0.46 \\
\hline Starch content & -0.66 & -0.67 & -0.41 \\
\hline Sugar content & -0.57 & -0.30 & -0.42 \\
\hline Crude fiber content & 0.87 & 0.37 & 0.57 \\
\hline \hline
\end{tabular}

\section{Comparison of Urban and Rural Hedonic Relationships}

The extended hedonic model explained $84 \%$ of the varieties in the price paid by urban consumers. For the rural consumers, the value dropped to $50 \%$. The high F-value of 29.3 and 4.88 for the urban and rural regressions, respectively, indicated that the regression coefficients were significantly different from zero. The independent variables were important in explaining the price variations. Results of the Chow test showed that the computed F-value of 20.29 was significant. This suggest that the effects of quality characteristics on the price of sweetpotato were not the same across urban and rural consumers.

\section{Hedonic Relationships by Income Group}

As income levels decreased, consumers became more discriminating. This is evident from the observation that the low-income consumers purchased sweetpotato based on quality characteristics and attached higher implicit prices to these characteristics than high-income consumers (Tables 3 and 4). This implies that as people's income 10 . 
increase and their standard of living rises, their consumption decreases. Among the shift variables only location is found to significantly affect price for the two income groups, implying that within income groups, prices paid by consumers vary depending on whether their purchase are made in urban or rural markets.

For all consumers, the most commonly cited reason for buying sweetpotato was freshness. Other criteria included reasonable price, freedom from injuries and decay and good taste.

Table 3. Estimated implicit price function, by income group, Ormoc and Villaba, Northwestern, Leyte.

\begin{tabular}{|l|r|r|}
\hline \multirow{2}{*}{ Item } & \multicolumn{2}{|c|}{ Income Group } \\
\cline { 2 - 3 } & \multicolumn{1}{|c|}{ High } & \multicolumn{1}{|c|}{ Low } \\
\hline Sweetpolato characteristics & 0.15 & 0.12 \\
\hline Size of roots & $(-0.62)$ & $(-0.88)$ \\
\hline & $1.70^{*}$ & 1.13 \\
\hline Ory malter content & $(-3.23)$ & $(-1.97)$ \\
\hline & 0.12 & 0.13 \\
\hline Protein content & $(0.76)$ & $(-0.90)$ \\
\hline & 0.11 & $0.81^{*}$ \\
\hline Starch content & $(-0.65)$ & $(-0.23)$ \\
\hline Sugar content & 0.28 & $0.46^{* *}$ \\
\hline & $(1.94)$ & $(-3.28)$ \\
\hline Crude fiber content & 0.07 & $0.39^{*}$ \\
\hline & $(0.99)$ & $(3.82)$ \\
\hline Consumer trait & & \\
\hline Age & $0.22^{\star *}$ & 0.19 \\
\hline & $(-4.23)$ & $(1.90)$ \\
\hline Education & 0.19 & 0.14 \\
\hline & $(0.24)$ & $(0.06)$ \\
\hline Location & $0.40^{* *}$ & $0.08^{* *}$ \\
\hline & $(4.25)$ & $(3.48)$ \\
\hline
\end{tabular}

Figures inparanthesis are t-values, ${ }^{* *}=$ significant at $1 \%$ level, ${ }^{*}=$ significant at $5 \%$ level 
Table 4. Mean implicit prices (f/unit) of characteristics paid by different income group, Ormoc and Villaba, Northwestern, Leyte.

\begin{tabular}{|l|r|r|}
\hline \multirow{2}{*}{\multicolumn{1}{|c|}{ Characteristics }} & \multicolumn{2}{|c|}{ Income Group } \\
\cline { 2 - 3 } & \multicolumn{1}{|c|}{ Urban } & \multicolumn{1}{c|}{ Rural } \\
\hline Size of roots & -0.12 & 0.10 \\
\hline Dry matter content & -1.09 & 0.73 \\
\hline Proteir content & 0.29 & -0.30 \\
\hline Starch content & -0.06 & -0.45 \\
\hline Sugar content & 0.28 & -0.48 \\
\hline Crude fiber content & 0.08 & 0.51 \\
\hline
\end{tabular}

\section{CONCLUSION AND RECOMMENDATION}

Based on the results of this study, the following conclusions can be drawn:

1. Consumers attach economic importance to sweetpotato quality. Both urban and rural consumers were responsive to changes in quality characteristics. There was a significant difference in the estimated price and quality relationships between urban and rural consumers.

2. Preference for sweetpotato quality vary somewhat among distinct consumer groups. Differences in characteristics preferred were noted among classes. Low-income consumers became more discriminating than high-income consumers and their willingness to pay for sweetpotato was dependent on quality characteristics. Likewise, within income groups, prices paid by consumers varied depending on whether purchase was made in urban or rural markets. 
3. Estimates of hedonic prices that are significant provide a measure of the value of different quality characteristics to consumers. These values yield estimates of the returns to research for improving quality and can be used to rank the importance of potential quality. improvements in setting research priorities. More important, the returns to quality improvements can be used to demonstrate the usefulness of further research.

The study has strong implications for sweetpotato research on breeding improvement and cultivation to produce qualities that better satisfy consumer needs. Future researchers could employ hedonic pricing in the study of sweetpotato qualities preferred by consumers in other localities. However, temporal differences in the markets must also be taken into considerations. It is; therefore recommended that similar studies be conducted in other localities that would provide benchmark information on sweetpotato qualities preferred by consumers to assist sweetpotato breeding programs. However, it is further suggested that hedonic sweetpotato model must also capture the temporal differences in the markets. Periodic survey should also be institutionalized to monitor consumer demand and preference patterns. Moreover, it is worthwhile to examine more specifically defined locations to accurately capture preference variations resulting from cultural or ethnic classes, religion and additional socio-economic characteristics for locational differences are affected not only by degree of urbanization. In order to get an accurate representation of the population being studied, stratification of respondents by income group must be done before sampling to generate better results. 


\section{LITERATURE CITED}

ABANSI, C.L., LANTICAN, F.A. and DUFF, B. 1991. Consumer demand for rice grain quality using the Hedonic Price Model. Jour. Agric. Econ. Dev. 21: 16-81.

BECKER, G.S. 1965. A theory of the allocation of time. Econ. Jour. 75: $493-517$.

CHOW, G.C. 1960. Test of equality between sets of coeffecients in two linear regressions. Economitrica. 28:591-605.

COLEMAN, D. and. YOUNG, T. 1989. Principles of Agricultural Economics: Markets and Prices in Less Developed Countries. Cambridge University Press, Cambridge.

GOLAN, A. and SHALIT. H. 1993. Wine quality differentials in hedonic grape pricing. Phil. Jour. Agric. Econ. 311-321.

HOUTHAKKER, H.S. 1952. Compensated changes in quantities and qualities consumed. Rev. Econ. Stud. 19:155-64.

LADD, G.W. and SUVANNUNT, V. 1976. A model of consumer goods characteristics. Amer. Jour. Agric. Econ. 58:504-510.

LANCASTER, K. 1966. Change and innovation in the technology of consumption. Amer. Econ. Rev. 56:132-157

PUTTOCK, G.D. et al. . 1990. Stumpage prices in Southwestern Ontario: A hedonic function approach. Forest Sci. Canad. Jour. Agric. Econ. 38:333-344. 
ROSEN, S. 1974. Hedonic prices and implicit markets: Product differentiation in pure competition. Jour. Agric. Econ. 82:3435.

\section{ABOUT THE AUTHOR}

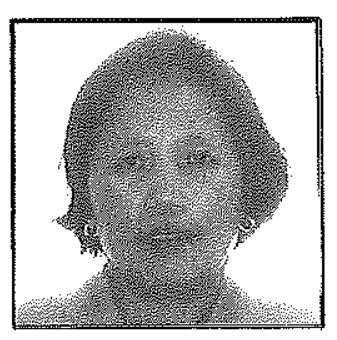

The author finished her Bachelor of Science in Agribusiness, March 1980 from the Visayas State College of Agriculture (ViSCA) now the Leyte State University (LSU). After graduation, she was hired as Secondary School Teacher at the Leyte National College of Science and Technology (LNCAST). After finishing her Master of Science degree under the VISCA-DECS Scholarship Grant in 1995, she took charge of the Higher Education Management Information System (HEMIS). The author is also a Doctor of Philosophy (Ph.D.) graduate in agricultural education at LSU under the VISCA-CHED Scholarship Grant and currently an Assistant Professor of LSU-Villaba campus.

The co-author is a professor in agricultural economics of the Department of Economics of Leyte State University. He served as the major adviser of the senior author when the latter was taking her M.S. in agricultural economics. 